\title{
THE IDENTIFICATION AND DISTRIBUTION OF GLYCINE LATROBEANA (MEISSN.) BENTH. IN TASMANIA
}

\author{
by A.J.J. Lynch
}

(with two tables and one text-figure)

LyNCH, A.J.J., 1994 (30:vi): The identification and distriburiøn of Glycine latrobeana (Meissn.) Benth. in Tasmania. Pap. Proc. R. Soc. Tasm. 128: 17-20. https://doi.org/10.26749/rstpp.128.17 ISSN 0080-4703. Department of Geography and Environmental Studies, University of Tasmania, GPO Box 252C, Hobart, Tasmania, Australia 7001 (formerly of Parks and Wildlife Service, Department of Environment and Land Management, Hobart).

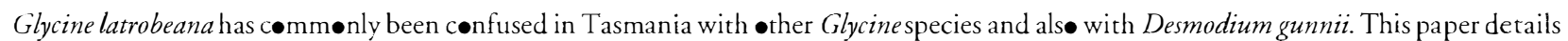

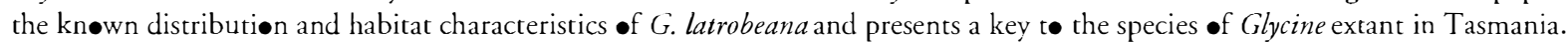
Key Words: Fabaceae, Glycine, Tasmania.

\section{INTRODUCTION}

Three species of Glycine occur in Tasmania: G. clandestina J.Wendl., G. latrobeana (Meissn.) Benth. and G. microphylla (Benth.) Tind. These species are all small, perennial, trifoliolate herbs, which may become trailing or twining if protected from grazing. Like many leguminous plants, they are palatable, and the species are restricted to dry sclerophyll woodlands where the populations are usually grazed by native herbivores. Consequently, wild plants tend to be small, comprising only a few short stems (up to $0.1 \mathrm{~m}$ length). In Tasmania, the three Glycine species can adopt similar habits, even if not intensively grazed, making identification difficult.

Glycine latrobeana has commonly been confused in Tasmania with the other Glycine species and also with Desmodium gunnii. Similar confusion within the Glycine genus has been noted in South Australia (Davies 1986). In Tasmania, this confusion has arisen from identifications based on growth habit as described in Curtis \& Morris (1975). These authors recognised only $G$. clandestina and G. latrobeana as present in Tasmania, and did not describe the variability inherent in $G$. clandestina. In addition, confusion has arisen temporarily from the results of cytological studies by CSIRO. These factors have resulted in the misidentification of Glycine species in surveys, especially the grasslands survey (Kirkpatrick et al. 1988), and in the literature (Duncan \& Harris 1983, Kirkpatrick et al. 1991). As a result, the extent of $G$. latrobeana in Tasmania has been overestimated. This paper details the known distribution and habitat characteristics of $G$. latrobeana, and presents a new key for distinguishing between species of Glycine extant in Tasmania. Nomenclature of plant species follows Buchanan et al. (1989), except for Desmodium gunnii (syn. Desmodium varians var. gunni which follows Hacker (1990).

\section{IDENTIFICATION}

The morphology of $G$. latrobeana was described in a revision of the genus and its immediate allies (Hermann 1962). Field identification of Glycine species is difficult because they are usually grazed, because they lack flowering or fruiting characters for much of the year, and also because of their ability to reproduce via both chasmogamous and cleistogamous inflorescences. G. tabacina has also been thought to occur in Tasmania, but has not been positively identified (J. Grace \& A. Brown, pers. comm.). The following section on identification is based on Tindale (1987), Jessop \& Toelken (1986), J. Grace \& A. Brown (pers. comm.) and personal observations.

A key to the four species of Glycine is presented in table 1, based on the stem, stipel, leaf and seed morphology. Additional characters distinguishing $G$. latrobeana from $G$. clandestina are that the former has trailing rather than twining stems, that it may spread rhizomatously, and also that it has orbicular to obovate leaflets rather than digitately trifoliolate leaflets (however, this characteristic is highly variable in Tasmanian specimens of $G$. clandestina, which may also have orbicular leaflets, especially when stems are young).

The chasmogamous flowers of the Glycine species are small, either purple or pink pea-flowers ascending in racemes from the axils of the upper leaves on long peduncles. Cleistogamous flowers are often solitary, frequently in the lower axils, and on very short peduncles. These flowers do not open but self-fertilise. The inflorescence of $G$. latrobeana is more compact than $G$. clandestina, being crowded near the ends of the peduncles rather than spread along the upper half. The pods of $G$. latrobeana are about $20-25 \mathrm{~mm}$ by $5 \mathrm{~mm}$ and contain 3-5 cylindrical-shaped seeds, whereas the pods of $G$. clandestina are c. $12-30 \mathrm{~mm}$ by $3-4 \mathrm{~mm}$ and contain 4-8 seeds (Weber 1986).

Desmodium gunnii is similar in appearance to $G$. latrobeana but is distinguishable by its hairless stems and lobed pod.

\section{DISTRIBUTION}

Glycine latrobeana is an uncommon species which usually occurs in the open grasslands of southeastern Australia (Mt. Lofty Ranges and southeastern region of South Australia, throughout Victoria except for the northwestern quarter, the far eastern section and the districts of Shepparton and Albury; Davies 1986).

Records in Tasmania older than 25 years (fig. 1) placed the species in the northwest at Circular Head $(1836,1837)$, and in the midlands (Folly Lagoon near Ross 1964) extending 
TABLE I

Key to Tasmanian Glycine Species*

1. Stems non-stoloniferous. Leaves digitately trifoliolate, the 3 leaflets equally petiolulate and subsessile (i.e. all petiolules equal lengths). Veins of leaflets coarsely reticulate within the larger areolae. Stipels of the median petiolule absent or minute.

1. Stems stoloniferous with adventitious roors at the nodes of above-ground stems. Growth habit prostrate. and/or twining. Leaves pinnately trifoliolate, the terminal leafiet inserted on a short but distinct petioluis, lateral leaflets subsessile. Stipels always present on the median petioluie. Seeds of chasmogamous legumes: 3-6, perisperm granular or smooth. Veins of the leaflets very finely reticulate within the larger areolac......

2. Stens elongate, growth habit twining, with shoots all from tire crown. Stipels absent on the mediar: petiolule. Stipules oblong to lanceolate. Seeds of chasmogamous legumes 9-12, with a brown-coloured. rough surface. Seeờs c. $1.5 \times 1-1.2 \mathrm{~mm}$.......................................................................................... Cindestina

2. Stems short, erect, decumbent or ascending, growth habit trailing and spreading rhizomatousiy. Periolite: densely covered with antrorse to reflexed hairs, obscuring stipels which are minute and caducolss. Stipute suborbicular to broadily ovate or reniform, as wide as long or wider, and wrapping around stem.

Seeds of chasmogamous legumes $3-5$, with a dark-brown, smooth to muriculate surface. Seeds $c .2-2.74$ $\times 1.75-2.25 \mathrm{~mm}$

3. Leaves weakly pinnately trifoliolate. Growth habit twining. Seeds $1.5-2.2 \times 1-2$ mm, perisperm smoothi G. microphylla

3. Leaves strongly pinnately trifoliolate. Growth habit trailing. Distinct, long stipules.

Seeds $2-2.5 \mathrm{~mm} \times 1.8-2.5 \mathrm{~mm}$, perisperm smooth or in some forms granular. Not recorded from

Tasmania

G. tabacina

*Adapted from Tindale 1987, Jessop \& Toelken 1986 and J. Grace \& A. Brown (pers. comm.)

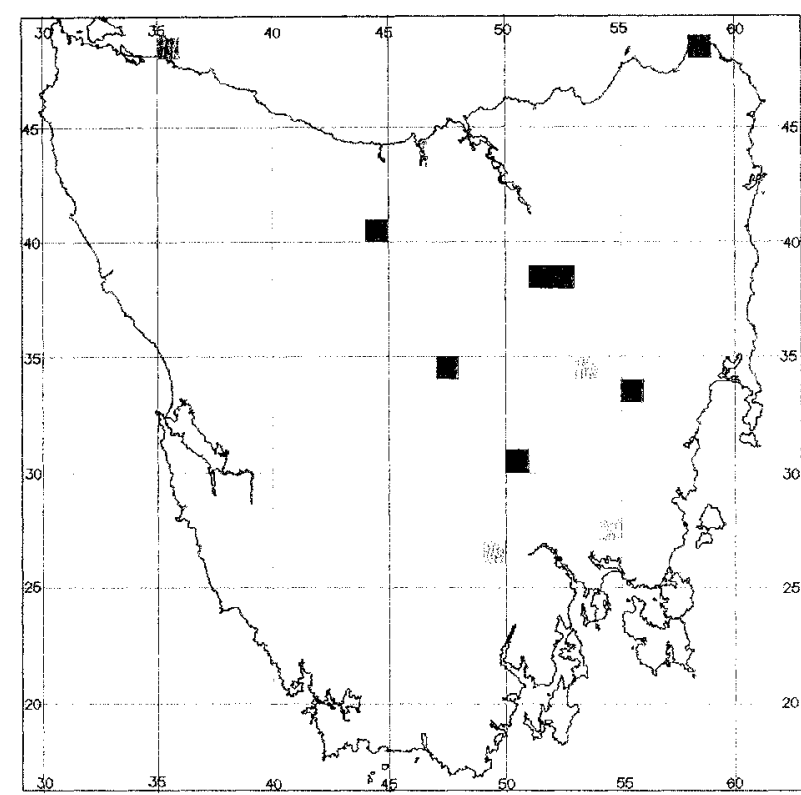

FIG. 1 - Distribution of Glycine latrobeana in Tasmania: recently recorded populations (dark shading), records older than 25 years (paler shading).

south to Runnymede (1848) and the Derwent Valley (Plenty 1839). None of these records has been verified recently. The current Tasmanian distribution of the species ( $f_{1} g .1$ ) appears to be in the midlands: from north of Epping Forest (Powranna Road 1991), at Stockers Bottorn (1981), and at Pig Farm Hill in the Bothwell area (1982); on the central plateau, at two sites along the Ouse River $(1980,1984)$; and at two near-coastal sites at Cape Portland, in the far northeast of the state $(1983,1991)$. Specimens of $G$. latrobeana from Pig Farm Hill and the upper Ouse River were identified by
CSIRO Plant Industry researchers Dr A. Brown and Dr Grace from field collections by DrM. Brown and F. Duncan. Two other sites without supporting specimens have also been recorded for G. latrobeana: Hummocky Hills in the midlands (M. Cameron, pers. comm. 1992) and Dogs Head Hill, north of Mole Creek in northern Tasmania (Duncan 1989).

Approximately 60 Glycine plants were observed on private land on the Powranna Road at the northern end of Epping Forest, midlands Tasmania, in 1991. The site was very small $(10 \mathrm{~m} \times 5 \mathrm{~m})$. It was located on a gentle slope above a poorly drained area of cleared native pasture and sedges, at an altitude of $170 \mathrm{~m}$. This site faced southeast and was situated on sandy loam on dolerite, amidst a Eucalyptus pauciflora and E. viminalis open woodland with a moderately dense, shrubby understorey. The understorey was dominated by Acacia dealbata and Pteridium esculentum. The ground layer was grassy, dominated by Themeda triandra, Poa sieberiana, Ehrharta stipoides, Stipa sp., Danthonia sp. and Aira caryophyllaea, and also with Lissanthe strigosa, Astroloma humifusum, Centaurium erythraed, Hypochoeris glabra, Plantago varia, Goodenia lanata, Brunonia australis and Pimelea humilis. The area was grazed by sheep, and also subject to woodcuting and frequent firing. The ground species were under considerable grazing pressure, with little regeneration observed of Brunonia australis and none of Glycine latrobeana (A. Pyrke, pers. comrn.). The weed gorse, Ulex europaeus, occurs near the site. $G$. Latrobeana has also been reported to occur five kilometres to the southwest, at Hummocky Hills (M. Cameron, pers. comm.).

Two Glycine species have been collected in the Stockers Bottom locality. $G$, clandestina was identified from one site (A. Brown \& j. Grace, pers. comm.), while one kilometre east, $G$. Latrobeana has been collected. The G. Latrobeana site was located on an undulating plateau at $420 \mathrm{~m}$ altitude on Triassic sediments. The community was localised and composed of a Eucalyptus viminalis-E. dalrympleana open 
forest marginal to a E. ovata-E. paucifiora-E. rodwayi frost hollow. The site had a high fire frequency, reflected in the heathy grassland understorey, which was dominated by the shrubs Acacia dealbata, Lissanthe strigosa, Acrotriche serrulata and Astroloma humifusum, the grasses Microlaena stipoides, Danthonia sp. and Poa rodwayi, and the herbs Viola spp.: Pimelea humilis, Acaena echinata, Plantago varia and Bossiaea prostrata. The site had been selectively logged and was grazed.

The site at Pig Farm Hill in the Bothwell district was also located on private land. The site was on the moderately sloping, northern aspect of a broad knoli at an altitude of $660 \mathrm{~m}$. The local rock-type was Jurassic dolerite, and the soils shallow. The vegetation community was a Eucalyptu: rubida and $E$. datrympleana woodiand with a shrubby understorey, primarily of Acacia dealbata and regenerating E. rubida. The ground cover consisted of moderately dense Lomandra longifolia, with Lissanthe montana, and a dense cover of the grasses Poa labillardieri, $P$. rodwayi and Danthonia sp. The herbs Pimelea humilis, Dichondra repens, Lagenifera stipitata, Geranium potentilloides and Senecio minimus were also present. This site had a frequent firing regime and was grazed by sheep.

Glycine latrobeana has been collected from a high altitude site $(900 \mathrm{~m})$ on the upper Ouse River, Miena district (1984). This site was a flat to undulating site on the top of a broad ridge above the river, near the Monpeelyata Canal. It comprised Eucalyptus pauciflora woodiand over a middense, low shrub layer of Cyathodes parvifolia, Leucopogon hookeri and Lomatia tinctoria, and a predominantly grassy ground cover of Poa gunnii, Elymus scabrus, Danthonia penicillata, Deyeuxia quadriseta and Dichelachne rara. The following herbs also contributed cover: Plantago paradoxa, Acaena novae-zelandiae, A. echinata, Geranium sessiliflorum and Glycine clandestina. The local geology was dolerite, and the site was fired at reasonably frequent intervais.

Closer to the Ouse River and near Remarkable Rock, $G$. latrobeana has been collected in flower and fruit (1980). This site was located in small meadows above the river at an altitude of $850 \mathrm{~m}$.

Two collections of this species have been made close to sea level at Cape Portland, in the far northeast of Tasmania. The first site was located on the neck of the Cape Portland headland (1983). Glycine was, however, extremely rare. It was located in pasture dominated by Zoysia, Trifolium, Cerastium, Plantago and Lomandra. The second site (1991) was located $4 \mathrm{~km}$ farther south, at Petal Point. G. latrobeana was localised and growing in sandy soil on a grassy flat.

One record exists of $G$. latrobeana at Dogs Head Hill, north of Mole Creek, on limestone at about $350 \mathrm{~m}$ elevation (Duncan 1989). This population was not relocated in late January 1992, although $G$. microphylla and D. gunnii were collected. $G$. Latrobeana may still be present at the site, since these two Glycine species are in coexistence on the Upper Ouse River; it was described as common on the northfacing lower and mid-slopes amidst grassy Eucalyptus amygdalina woodland (Duncan 1989). These slopes were frequently fired. The low-to-medium understorey was dense and included Acacia dealbata, A. melanoxylon, Pultenaea juniperina, Lomatia tinctoria, Bossiaea riparia and Acrotriche serrulata. The ground layer was also dense, comprising Pteridium esculentum, Lomandra longifolia, Lepidosperma laterale, Dianella sp. and the grasses Elymus scabrus, Danthonia pilosa, Themeda australis, Poa sp., Ehrharta stipoides, Dichelachne rara and Deyeuxia quadriseta.
The preferred habitat of $G$. latrobeana appears to be on well-drained and insolated sites with a dolerite substrate or sandy soils, usualiy on flats or gentle slopes of plains, ridgelines, or valleys (tabie 2). The sites vary from near sea level to $900 \mathrm{~m}$ altitude, but tend to be in dry scierophyll, shrubby woodiand, often with a dense grass component of the ground layer, and dominated by Eucalyptus viminalis, $E$. paucifiora or E. dairympleana. The species may also occur in grasslands. Some overstorey cover appears to be required in the midlands populations, so a balance must be achieved between regeneration of canopy species with maintenance of an open shrubby to grassy understorey.

Itts regeneration ecology appears to be typical of $\mathrm{dry}$ sclerophyll species. The species produces hard seeds, which may join the soil-storcd seed bank and germinate after mild to hot fires. G. latrobeana may also resprout, a characteristic enhanced by its thickened tap-root. This tap-root enables the species to lie "dormant" through winter, and reshoot, flower and fruit in late spring to eariy summer. The timing of grazing is, therefore, very important to the survival of this species. Although the seed persists in the soil, spring-summer grazing over many years combined with frequent firing will deplete the seed bank and the capacity of the species to persist. The seed has a high viability and probable longevity but is not known to be easily or commonly dispersed. The sites are usually very localised, and most are subject to frequent firing and grazing. All sites are, therefore, important to the survival of the genetic diversity of this species in Tasmania.

\section{CONSERVATION STATUS OF GLYCINE LATROBEANA}

Glycine latrobeana was listed nationally as rare (3RCa), with a distribution over more than $100 \mathrm{~km}$, and considered adequately reserved (Briggs \& Leigh 1988). More populations have been found in Victoria (J. Grace, pers. comm.), but the species is still considered nationally to be vulnerable (ANZECC 1993). In Tasmania, there are seven populations recently recorded, two of which need to have specimens collected for the Tasmanian Herbarium. There are also two other sites which need to be confirmed. The sites are widespread but extremely restricted, usually over areas tens of metres across. They also tend to contain less than 60 plants at a site. The species is unreserved and should be upgraded from rare (r3 - Kirkpatrick et al. 1991) to vulnerable at both the state and national levels (Vuv Lynch 1993).

\section{ACKNOWLEDGEMENTS}

The assistance of Phil Barker, Tony Brown, Alex Buchanan, Fred Duncan, Jim Grace, Colin Reed and Mary Tindale was appreciated. Comments on the draft manuscript by Jamie Kirkpatrick, Stephen Harris, Mick Brown and an anonymous referee were also appreciated. This research was funded under a grant from the Endangered Species Programme, Australian National Parks and Wildlife Service to the Parks and Wildlife Service, Tasmania. 
TABLE 2

Summary of habitat records and conservation information for Glycine latrobeana

\begin{tabular}{|c|c|c|}
\hline Recent records: & \multicolumn{2}{|l|}{$7(-9)$ extant sites } \\
\hline Habit: & \multicolumn{2}{|c|}{ Small, perennial trifoliolate herb, trails across ground if protected from grazing } \\
\hline Population size: & \multicolumn{2}{|c|}{$<500$} \\
\hline Regeneration: & Type: & Presumed from soil-stored seed, not observed \\
\hline \multirow[t]{5}{*}{ Habitat: } & Landform: & (Flat ridgetops) - gentle slopes of plains, ridgelines, valleys \\
\hline & Altitude: & Near sea level-900 m \\
\hline & Aspect: & North to southeast \\
\hline & Slope: & Gentle (usually $<10^{\circ}$ ) \\
\hline & Community: & $\begin{array}{l}\text { Dry sclerophyll shrubby to grassy woodland (Eucalyptus viminalis, E. patuciflora, E. } \\
\text { dalrympleana), may be in pasture }\end{array}$ \\
\hline Fire response: & \multicolumn{2}{|c|}{$\begin{array}{l}\text { May resprout; significant seed germination of } G \text {. clandestina after moderate intensity burns (Auld \& } \\
\text { O'Connell 1991) }\end{array}$} \\
\hline \multirow[t]{2}{*}{ Conservation status: } & Recommended: & Vuv \\
\hline & Current: & (V - ANZECC 1993; r3 - Kirkpatrick et al. 1991; 3RCa - Briggs \& Leigh 1988) \\
\hline \multirow[t]{2}{*}{ Comment: } & \multicolumn{2}{|c|}{ Unreserved } \\
\hline & \multicolumn{2}{|c|}{$\begin{array}{l}\text { Herbarium specimen not collected from site at Dogs Head Hill, Mole Creek (proposed reserve), and } \\
\text { population may actually have been G. microphylla }\end{array}$} \\
\hline
\end{tabular}

\section{REFERENCES}

ANZECC, 1993: Proposed list of threatened Australian flora. Unpubl. rep.for Australian and New Zealand Environment and Conservation Council (ANZECC) by ANZECC Endangered Flora Network.

Auld, T.D. \& O'Connei.l, M.A., 1991: Predicting patterns of post-fire germination in 35 eastern Australian Fabaceae. Aust. J. Ecol. 16: 53-70.

Briggs, J.D. \& LEIGH, J.H., 1988: RARE OR THREATENED AUSTRALIAN PLANTS. Aust. Nat. Pks or Wildl. Serv. Spec. Publ. 14.

Buchanan, A. M., MoGeary-Brown, A. \& Orchard, A.E., 1989: A CENSUS OF THE VASCULAR PLANTS OF TASMANIA. Tasm. Herb. Occ. Publ. 2.

CurTis, W.M. \& MORRIS, D.I., 1975: THE STUDENT'S FLORA OF TASMANIA. PART 1. Second edn, Government Printer, Tasmania.

DAVIES, R.J.-P., 1986: THREATENED PLANT SPECIES OF THE MOUNT LOFTY RANGES AND KANGAROO ISLAND REGIONS OF SOUTH AUSTRALIA. Conservation Council of South Australia, Adelaide.

Duncan, F., 1989: Vegetation of proposed Dogs Head Hill Forest Reserve. Unpubl, rep. Tasm. For. Commn, Hobart.

Duncain, F. \& Harris, S., 1983: A botanical survey in the Colonels Hills, an area of dry sclerophyll bushland near Tooms Lake. Tasm. Nat. 75: 5-16.

HACKER, J.B., 1990: A GUIDE TO HERBACEOUS AND SHRUB LEGUMES OF QUEENSLAND. University of Queensland Press, Brisbane.

HermanN, F.J., 1962: A revision of the genus Glycine and its immediate allies. U.S. Dep. Agric. Tech. Bull. 1268: 179 .

Jessop, J.P. \& TOElkEN, H.R. (Eds), 1986: FLORA OF SOUTH AUSTRALIA. PART II. LEGUMINOSAE-RUBIACEAE. South Australian Government Printing Division, Adelaide and the Flora and Fauna of South Australia Handbook Committee.

Kirkpatrick, J., Gilfedder, L. \& Fensham, R., 1988: CITY PARKS AND CEMETERIES - TASMANIA'S REMNANT GRASSLANDS AND GRASSY WOODLANDS. Tasmanian Conservation Trust, Hobart.
Kirkpatrick, J.B., Gilfedder, L., Hickte, J. \& Harris, S., 1991: Reservation and conservations status of Tasmanian native higher plants. Wildl. Div. Sci. Rep. 91/2. Dep. Pks, Wildl. \& Heritage, Tasm.

LYNCH, A.J.J., 1993: Conservation biology and management of 16 rare or threatened Fabaceae species in Tasmania. Aust. Nat. Pks of Wildl. Serv., Endangered Species Programme, Project No. 4. Pks \& Wildl. Serv., Hobart.

TindAIE, M.D., 1987: Taxonomic notes on three Australian and Norfolk Island species of Glycine Willd. (Fabaceae: Phaseolae) including the choice of a neotype for $G$. clandestina Wendl. Brunonia 9: 179-191.

Weber, J.Z., 1986: Subfamily 3 - Papilionoideae. In Jessop, J.P. \& Toelken, H.R. (Eds): FLORA OF SOUTH AUSTRALIA. PART II. LEGUMINOSAE-RUBIACEAE. South Australian Government Printing Division, Adelaide 8 the Flora and Fauna of South Australia Handbooks Committee: $569-709$.

\section{(accepted 3 August 1993)}

\section{Selected Glossary}

(adapred from Curtis \& Morris 1975)

areolae:

spaces, usually angular, marked out on a surface by ridges or cracks

caducous: falling at an early stage or prematurely

chasmogamous: of flowers which are cross-pollinated

cleistogamous: of flowers which are self-fertilised

petiolule: the stalk of a leaflet

stipel: one of a pair of outgrowths that may occur at the base of a leaflet stalk, i.e. stipule of a leaflet trifoliolate: having a compound leaf or leaves each with three leaflets 


\title{
VARIATION IN EUCALYPTUS BARBERIL. JOHNSON \& BLAXELL
}

\author{
by A.C. McEntee, B.M. Potts and J.B. Reid
}

(with three tables and four text-figures)

\begin{abstract}
McENTt:, A.C., Potts, B.M. \& Rm, J.B., 1994 (30:vi): Variation in Eucalyptus barberi L. Johnson \& Blaxell. Pap. Proc. R. Soc. Tasm. 128 : 21-30. ISSN 0080-4703. Department of Plant Science, University of Tasmania, GPO Box 252C, Hobart, Tasmania, Australia 7001.
\end{abstract}

Phenetic variation within Eucalyptus barberi $\mathrm{I}$. Johnson \& Blaxell was examined and compared to related Tasmanian species. "Typical" northern populations were morphologically distinct from the more diverse group of populations to the south. This pheneric disjuncrion did not correspond to the major geographic disjunction in the range of $E$. barberi. Detailed study of two morphologically aberant populations indicared that they probably arose from in situ hybridisation; however, the exact identicies of the progenitor species remains unclear. The rype locality and several of the "southern" populations, as well as aberrant populations at Meredith Tier and Ponybortom Creek, deserve formal conservation.

Keywords: Eucalyptus barberi, genetic variation, hybridisation, rare endemic, conservation, Tasmania.

\section{INTRODUCTION}

The past environment of the east coast is less well understood than that of other regions of Tasmania (e.g. sourhwestern Tasmania, MacPhail \& Colhoun 1985). In addition, the Eastern Tiers have received little botanical study until relatively recently (Duncan et al. 1981, Kirkparrick 1981). Kirkpatrick \& Brown (1984b) suggested that the geographic and habitat patterns of many species on the east coast result from limited radiation from separate glacial refugia. Their study of endemism in Tasmania suggested two centres of endemism on the east coast, implying at least two past glacial refugia (Kirkpatrick \& Brown 1984b).

Eucalypts in this region exhibit interesting biogeographic and genetic patterns of uncertain origin. These include unexplained north-south range disjunctions (e.g. Eucalyptus tenuiramis - Wiltshire et al. 1991), absences from apparently suitable habitats in the northeastern mountains (E. coccifera, E. umigera, E. subcrenulata and E. johnstonit - Potts 1990), and the unlikely presence of high-altitude species on low-altitude hills (E. cocciferd-Shaw et al. 1984). In addition, species that are morphologically and ecologically distinct in the sourheast appear to converge in both morphology and substrate preference in the east $(E$. pulchella, E. amygdalina and E. tenuiramis - Kirkpatrick \& Brown 1984b). Other species exhibit marked genetic differentiation between eastern and southeastern populations (e.g. E. cordata - Potts 1989), and patches comprising individuals outside the typical phenorypic range of currently described species are regularly encountered (e.g. Potts 1989, Potts \& Reid 1985b).

The present study examines population differentiation in the rare Tasmanian endemic E. barberi, that is distributed as a series of small, disjunct populations on the east coast of Tasmania (Kirkpatrick 1981, Pryor \& Briggs 1981). In addicion, several small, variable populations with some affinity to $E$. barberi are examined. $E$, barberi is restricted to the northern slopes of dry, low-altitude, dolerite ridges, most of which are unreserved crown or private land (Duncan 1989). E. barberi was first described informally by Barber (1954). It was formally described by Johnson \& Blaxell (1972), who considered that it had obvious affinities to
E. ovata, E. camphora and E. yarraensis and therefore placed it in the informal subseries Ovatinae (series Ovatae, section Maidenaria, subgenus Symphyomyrtus) of Pryor \& Johnson (1971). Ladiges et al. $(1981,1984)$ included one population in phylogenetically oriented studies of juvenile and seedling characters within the series. Chippendale (1988) has since redefined the series Foveolatae, which also includes E. aggregata, E. rodwayi and E. brookeriana (Gray 1979). The affinities of E. barberi to other Tasmanian Foveolatae species are also examined.

\section{MATERIALS AND METHODS}

\section{Sampling}

Sites were chosen that encompassed the full geograptic range of E. barberi (fig. 1, table 1), including the type locality (east Cherry Tree Hill; site 4). Representative samples of the other Tasmanian Foveolatae species (E. brookeriana A.M. Gray, E. ovata Labill. and E. rodwayi Baker \& Smich) were also included for comparison with $E$. barberi.

Atypical phenotypes with some affinities to E. barberi grow at Meredith Tier (sites 10-11) and Ponybottom Creek (sites 12-13). At Meredith Tier, samples were located along a transect (4-8 trees from each of 7 sites) to capture a distinct spatial gradient of atypical phenotypes over about $1 \mathrm{~km}$. Eleven trees were also sampled from an isolated stand, with apparent affinities to E. barberi, $1 \mathrm{~km}$ away (site 6). There was no evident spatial pattern of phenotypes at Ponybottom Creek. Consequently ten trees were sampled, in each of three subjective classes:

(1) narrow green foliage, resembling E. barberi (site 12), (2) glaucous, broad-leaved phenotypes with apparent affinities to E. gunnii or E. cordata (site 13), and

(3) phenotypes intermediate between these extremes.

Nine trees were sampled from the nearest population with affinities to E. barberi (Ringrove Razorback, site 9), $1.5 \mathrm{~km}$ away. A range of eastern populations of $E$. cordata, E. gunnii, $E$ archeri, E. johnstonii and E. subcrenulata were sampled, including those proximal to the Meredith Ticr (sites 10 11) and Ponybottom Creek (sites 12-13) sites, because 
TABLE 1

Populations sampled for this study

\begin{tabular}{|c|c|c|c|c|c|c|c|c|c|c|}
\hline \multirow[t]{2}{*}{ Species } & \multirow[t]{2}{*}{ Sample location } & \multirow{2}{*}{$\begin{array}{l}\text { Site } \\
\text { code }\end{array}$} & \multicolumn{2}{|c|}{ AMG ref.* } & \multirow{2}{*}{$\begin{array}{l}\text { Alt } f \text {. } \\
(\mathrm{m})\end{array}$} & \multirow{2}{*}{$\begin{array}{c}\text { Popn† } \\
(\min )\end{array}$} & \multicolumn{4}{|c|}{ Number sampleds } \\
\hline & & & East & North & & & $\mathrm{AP}$ & $J P$ & $\mathrm{AH}$ & $\mathrm{JH}$ \\
\hline \multirow[t]{9}{*}{ Eucalyptus barberi } & Blindburn Hill North & 1 & 6022 & 53678 & 220 & 400 & 12 & 22 & 12 & 22 \\
\hline & Blindburn Hill South & 2 & 6024 & 53663 & 200 & 30 & 11 & 24 & 11 & 24 \\
\hline & Cherry Tree Hill West & 3 & 5943 & 53528 & 180 & 40 & 9 & 23 & 9 & 23 \\
\hline & Cherry Tree Hill East & 4 & 5948 & 53518 & 170 & 60 & 12 & 16 & 12 & 16 \\
\hline & Brushy Creek & 5 & 5762 & 53478 & 440 & 60 & 10 & 18 & 10 & 18 \\
\hline & Meredith Tier & 6 & 5770 & 53297 & 400 & 30 & 11 & 35 & - & - \\
\hline & Lily Flats (South of) & 7 & 5718 & 53161 & 320 & 60 & 13 & 25 & 13 & 25 \\
\hline & Ravensdale Hill & 8 & 5713 & 53079 & 140 & 18 & 9 & 22 & 9 & 22 \\
\hline & Ringrove Razorback & 9 & 5735 & 52713 & 160 & 30 & 9 & 21 & - & - \\
\hline \multirow[t]{6}{*}{ Uncertain } & Meredith Tier & 10 & & & & & 7 & 29 & 7 & 29 \\
\hline & intermediate & - & 5767 & 53301 & 440 & 200 & - & - & 25 & 96 \\
\hline & glaucous & 11 & & & & & 6 & 37 & 6 & 37 \\
\hline & Ponybottom Ck green & 12 & & & & & 10 & 37 & 10 & 37 \\
\hline & intermediate & - & 5736 & 52723 & 180 & 60 & - & - & 13 & 42 \\
\hline & glaucous & 13 & & & & & 10 & 41 & 10 & 41 \\
\hline \multirow[t]{5}{*}{ E. brookeriana } & Buckbys Road & 14 & 3633 & 54602 & 120 & - & 4 & - & - & - \\
\hline & Elephant Pass & 15 & 6020 & 53908 & 390 & - & - & 4 & - & - \\
\hline & E. brookeriana type & 16 & 5705 & 53420 & 600 & - & 1 & 1 & - & - \\
\hline & Rocka Rivulet & 17 & 5700 & 53205 & 450 & - & 2 & 5 & - & - \\
\hline & Kellevie Plateau & 18 & 5670 & 52663 & 340 & - & 1 & 5 & - & - \\
\hline \multicolumn{2}{|c|}{ Pooled E. brookeriana } & BR & \multicolumn{3}{|c|}{ sites: $14-18$} & - & 8 & 18 & - & - \\
\hline \multirow[t]{4}{*}{ E. ovata } & Robbins Road & 19 & 3210 & 54855 & 20 & - & 5 & - & - & - \\
\hline & Bass Highway & 20 & 3990 & 54575 & 10 & - & 6 & - & - & - \\
\hline & W Road & 21 & 5727 & 52758 & 40 & - & 8 & 13 & - & - \\
\hline & Hobart College & 22 & 5250 & 52480 & 280 & - & 9 & 15 & - & - \\
\hline \multicolumn{2}{|c|}{ Pooled northwest coast $E$. ovata } & WO & \multicolumn{3}{|c|}{ sites: $19-20$} & - & 8 & 13 & - & - \\
\hline \multirow[t]{2}{*}{ E. rodwayi } & Steppes & 23 & 4910 & 53375 & 800 & - & - & 19 & - & - \\
\hline & M Road South & 24 & 5698 & 53233 & 580 & - & 7 & 12 & - & - \\
\hline \multirow[t]{8}{*}{ E. cordata } & Bluestone Tier & 25 & 5652 & 52932 & 350 & - & 10 & 18 & 10 & 18 \\
\hline & Brown $\mathrm{Mt}$ & 26 & 5428 & 52837 & 710 & - & 7 & 13 & 7 & 13 \\
\hline & Perpendicular Mt top & 27 & 5933 & 52766 & 340 & - & - & - & 10 & - \\
\hline & Perpendicular Mt low & 28 & 5930 & 52765 & 240 & - & - & - & 10 & - \\
\hline & Square $\mathrm{Mt}$ & 29 & 5506 & 52695 & 370 & - & 9 & 6 & 9 & 6 \\
\hline & Hospital Creek & 30 & 5673 & 52660 & 240 & - & - & - & 10 & - \\
\hline & Chimney Pot Hill & 31 & 5225 & 52476 & 430 & - & - & - & 10 & - \\
\hline & Cape Queen Elizabeth & 32 & 5345 & 52109 & 100 & - & - & - & 10 & - \\
\hline E. archeri & Mt Maurice & 33 & 5490 & 54260 & 1000 & & & 13 & - & 13 \\
\hline \multirow[t]{5}{*}{ E. gunnii } & Mt Arthur NE & 34 & 5208 & 54283 & 500 & - & - & - & 10 & - \\
\hline & Mt Victoria & 35 & 5687 & 54228 & 790 & - & - & - & 20 & - \\
\hline & Snow Hill & 36 & 5693 & 53592 & 950 & - & - & - & 25 & 15 \\
\hline & Pensford & 37 & 4837 & 53487 & 960 & - & - & - & 20 & - \\
\hline & M Road North & 38 & 5732 & 53298 & 640 & - & 11 & 32 & 11 & 32 \\
\hline \multirow[t]{2}{*}{ E. johnstonii } & Springs, Mt Wellington & 39 & 5190 & 52490 & 600 & - & - & 10 & - & - \\
\hline & Snug Plains & 40 & 5133 & 52330 & 600 & - & - & 5 & 16 & - \\
\hline \multirow[t]{2}{*}{ E. subcrenulata } & Dove Lake & 41 & 4135 & 53870 & 960 & - & - & 12 & - & - \\
\hline & Lake Charles & 42 & 4367 & 53633 & 1070 & - & - & 10 & - & - \\
\hline
\end{tabular}

* Australian Map Grid reference. † Altitude (metres). † Minimum estimate of population size for E. barberi populations. $\$$ Number of individuals sampled for population studies: variation in $E$. barberi and related species ( $\mathrm{AP}=$ adults, JP $=$ juveniles); aberrant populations at Meredith Tier and Ponybottom Creek, sites 10-13 and intermediates ( $\mathrm{AH}=$ adults, JH $=$ juveniles).

S Seed collected from open pollinated offspring from type specimen of E. brookeriana, grown as an ornamental. 


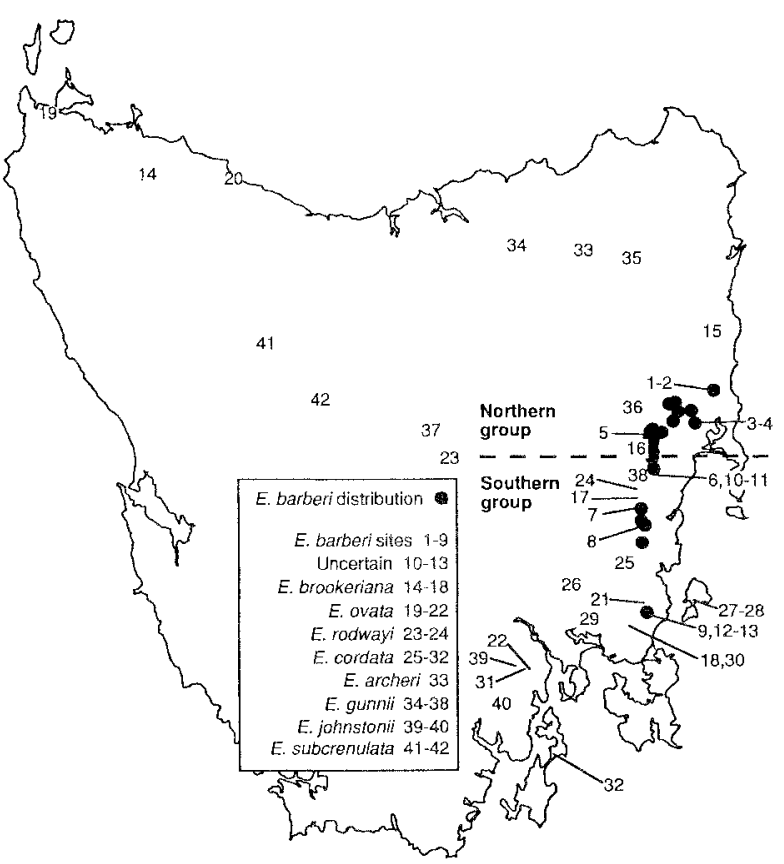

FIG. 1 - The known distribution of Eucalyptus barberi (- - from Forestry Commission of Tasmania records) and locations of populations of all species sampled for this study (codes). (Location codes are detailed in table 1.) An explanation of "northern" and "southern" groups is given in the discussion.

some atypical phenotypes showed affinities to these species. Adult data from previous studies were also used for $E$. gunnii, E. archeri (Potts \& Reid 1985b) and E. cordata (Potts 1989). Open-pollinated seed, as well as three typical, mature canopy leaves and capsules, was collected from up to 13 trees, at least two tree-heights apart, from each $E$. barberi population (see table 1, AP).

\section{Progeny trial}

Seeds were germinated on a 1:1 vermiculite:gravel mix covered with a surface $(20 \mathrm{~mm})$ of vermiculite. At the cotyledonary stage (three weeks) plants were transplanted into black plastic potting bags filled with potting mix. Plants were grown under glasshouse conditions (day $19^{\circ}$ $24^{\circ} \mathrm{C}$, night $12^{\circ}-14^{\circ} \mathrm{C}$ ) with the natural photoperiod extended to $18 \mathrm{~h}$ by a mixed incandescent and fluorescent light source.

Four seedlings from each of approximately 12 families were used in the progeny trial and were placed in a completely random design. Between 16 and 25 individuals were scored for each typical E. barberi population (numbers sampled from each populations are shown in rable 1, JP). E. brookeriana samples (sites 14-18) were pooled (BR) for the purposes of the analysis. Similarly, northwest coast E. ovata populations (sites 19-20) were treated as one population sample (WO).

\section{Morphometric data collection and analysis}

The characters scored from adult and juvenile plants are listed in table 2. Capsule and adult leaf characters are the same as those described in Potts \& Reid (1985b). Adult data analysis was performed on the means of three replicates from each tree. Seedlings were scored six months after planting. Measurement of the juveniles was based upon characters (table 2) recognised as distinguishing E. barberi from other members of the Foveolatae (LAML8, LAMW8, LWP8, PETL8, RUG, GLAND, CREN, LATLEN, LATRAT and INTLEN), E. johnstonii and E. subcrenulata (DIARAT, COLOUR), and E. cordata and E. gunnii (LOBE8, GLAU, INTRANOD, PETNODE; Chippendale 1988). Juvenile leaf characters were measured from a leaf removed from the eighth node (counting the cotyledonary node as node 0 ), and stem characters from the eighth internode (below node 8). Categorical multistate characters measured on relative scales were scored by comparison with standards (GLAND, CREN, RUG, GLAU, COLOUR). DIARAT (diameter ratio $=$ widest width/narrowest width at the same height on the stem) represented the rectangularity of the stem. INTLEN (mean internode length) was calculated as the height/ the number of internodes. LATRAT (lateral ratio $=$ number of nodes with laterals/number of nodes) represented the proportion of the plant bearing lateral branches.

The pooled within-population residuals for each variable were tested for normality, using the UNIVARIATE procedure of SAS (SAS 1988). The relationship between residuals and fitted values, derived from the one-way GLM analysis (SAS 1988), was inspected in bivariate plots. Where necessary, transformations were used that optimised the normality and homogeneity of variance criteria. Variables and transformations used in the analysis are shown in table 2. Stepwise discriminant analysis (STEPDISC procedure of $S A S)$ found that all variables were significant $(p<0.05)$ in separating populations.

Parametric canonical discriminant analysis was performed using the CANDISC procedure of SAS; this produced discriminant functions, which maximised the separation of populations. Means and standard errors were calculated for each population from the individual scores along the discriminant functions. The relative importance of different characters in differentiating populations, and their direction of variation in the discriminant space, were summarised by plotting vectors, the lengths of which are proportional to the univariate F-values, the directions being determined by the standardised canonical coefficients of the relevant discriminant functions. Populations were also clustered, using average linkage cluster analysis (Sneath \& Sokal 1973) based on the matrix of Mahalanobis' distances. Mahalanobis' distances between populations were calculated from the squared Euclidean distance between populations, in the space defined by the first nine discriminant axes (representing $99.3 \%$ of adult and $94.9 \%$ of juvenile variation for the populations shown in fig. 3). This procedure was applied to adult and juvenile (table 1: AP, JP respectively) E. barberi (sites 1-9) and other Foveolatae populations (E. brookeriana - BR; E. ovata-WO, sites 21-22; E. rodwayi, sites 23-24), including the green phenotypes resembling $E$. barberi from Meredith Tier (site 10) and Ponybottom Creek (site 12). For comparison with other species, this analysis was repeated, with the addition of samples from populations of $E$. johnstonii (sites 39-40), E. subcrenulata (sites 41-42), E. gunnii-archeri 
TABLE 2

Morphological characters measured for this study

\begin{tabular}{|c|c|c|c|c|c|}
\hline Code & Description & Scale* & Trans. $\dagger$ & \multicolumn{2}{|c|}{ Significancet } \\
\hline \multicolumn{4}{|c|}{ Adult leaf characters } & $F_{15,140}$ & $\operatorname{Pr}>F$ \\
\hline $\mathrm{LL}$ & Lamina length & $\mathrm{mm}$ & $\log$ & 8.42 & 0.0001 \\
\hline LW & Lamina width & $\mathrm{mm}$ & $\log$ & 13.9 & 0.0001 \\
\hline LWP & Length to widest point & $\mathrm{mm}$ & $\log$ & 4.73 & 0.0001 \\
\hline PET & Petiole length & $\mathrm{mm}$ & $\log$ & 8.93 & 0.0001 \\
\hline \multicolumn{6}{|c|}{ Adult capsule characters } \\
\hline PEDI & Pedicel length & $\mathrm{mm}$ & $\log$ & 9.39 & 0.0001 \\
\hline PEDU & Peduncle length & $\mathrm{mm}$ & $\log$ & 6.71 & 0.0001 \\
\hline CAPL & Capsule length & $\mathrm{mm}$ & $\log$ & 19.2 & 0.0001 \\
\hline MAXW & Capsule max. width & $\mathrm{mm}$ & $\log$ & 13.8 & 0.0001 \\
\hline PTMW & Length to max. width & $\mathrm{mm}$ & $\log$ & 6.69 & 0.0001 \\
\hline RIMW & Rin width & $\mathrm{mm}$ & square & 5.18 & 0.0001 \\
\hline VPOS & Valve thickness & $(1-4)$ & square & 2.92 & 0.0005 \\
\hline VSIZE & Valve size & $(1-4)$ & $\log$ & 1.97 & 0.0212 \\
\hline \multicolumn{4}{|c|}{ Juvenile leaf characters } & $F_{15,333}$ & \\
\hline LAML8 & Lamina length & $\mathrm{mm}$ & - & 4.85 & 0.0001 \\
\hline LAMW8 & Lamina width & $\mathrm{mm}$ & - & 13.2 & 0.0001 \\
\hline LWP8 & Length to widest point & $\mathrm{mm}$ & - & 5.81 & 0.0001 \\
\hline PETL8 & Petiole length & $\mathrm{mm}$ & - & 1.58 & 0.0001 \\
\hline LOBE8 & Lobe length from leaf base to bottom of lobe & $\mathrm{mm}$ & - & 7.63 & 0.0001 \\
\hline GLAND & Gland density on leaf & $(1-4)$ & - & 8.27 & 0.0001 \\
\hline CREN & Crenulation of margin & $(1-3)$ & - & 5.51 & 0.0001 \\
\hline \multicolumn{6}{|c|}{ Juvenile stem characters } \\
\hline RUG & Rugoseness & $(1-3)$ & $\log$ & 14.7 & 0.0001 \\
\hline DIARAT & Stem rectangularity & - & - & 2.53 & 0.0014 \\
\hline \multicolumn{6}{|c|}{ Juvenile whole plant characters } \\
\hline INTRANOD & Node 1st intranode & - & - & 10.6 & 0.0001 \\
\hline PETNODE & Node of Ist petiole & - & - & 9.32 & 0.0001 \\
\hline INTLEN & Mean internode length & $\mathrm{mm}$ & - & 7.04 & 0.0001 \\
\hline LATLEN & Length longest lateral & $\mathrm{mm}$ & - & 4.13 & 0.0001 \\
\hline LATRAT & Lateral ratio & - & - & 3.14 & 0.0001 \\
\hline GLAU & Glaucousness & $(0-8)$ & - & 3.12 & 0.0001 \\
\hline \multirow[t]{2}{*}{ COLOUR } & $\begin{array}{l}\text { Max. node where anthocyanin occurs on } \\
\text { the undersurface of the leaf }\end{array}$ & & & & \\
\hline & $0-10 \times$ Depth of colour $(0,1, \ldots 3)$ & $(0-30)$ & - & 2.15 & 0.0079 \\
\hline
\end{tabular}

* Numbers in parentheses represent relative scales.

$\uparrow$ Transformation used.

$\mp$ Univariate significance of variation in each character between populations in the series Foveolatae.

(sites 33, 36, 38), E. cordata (sites 25-26, 29), and the most glaucous phenotypes from Meredith Tier (site 11) and Ponybottom Creek (site 13).

For analysis of the Meredith Tier and Ponybottom Creek samples, quadratic discriminant functions were calculated for both adult and juvenile data sets, which maximised the separation between typical populations of $E$. barberi (sites 1-5, 7-8), E. gunnii (sites 34-38) and E. cordata (sites 2532). The latter procedure takes into account the differences in variance/covariance structures between species. Mean discriminant scores and 95\% confidence intervals for individuals from the reference groups were calculated. Discriminant scores for individuals from Meredith Tier (sites $10-11$ and intermediates) and Ponybottom Creek (sites 12-13 and intermediates) were also calculated on the two discriminant functions derived from this analysis.
In order to determine whether an individual falls within the range of variation encompassed by each reference species (E. barberi, E. gunnii, E. cordata), the generalised distance of each individual tree from the centroid of each species, and its significance were calculated according to equations 5.1 and $5.2 b$ in Orlóci (1978), using separate variancecovariance matrices for each species (and equal sample sizes). An individual was classified as falling within the range of variation encompassed by a species if the probability of obtaining the observed generalised distance due to chance alone was greater than 0.05 (i.e. the individual falls within the multivariate $95 \%$ confidence interval of the species). For each of the three reference species, the proportions of adult individuals in each population that matched the reference species phenotype were calculated, as well as the proportion of individuals whose phenotype did not match 

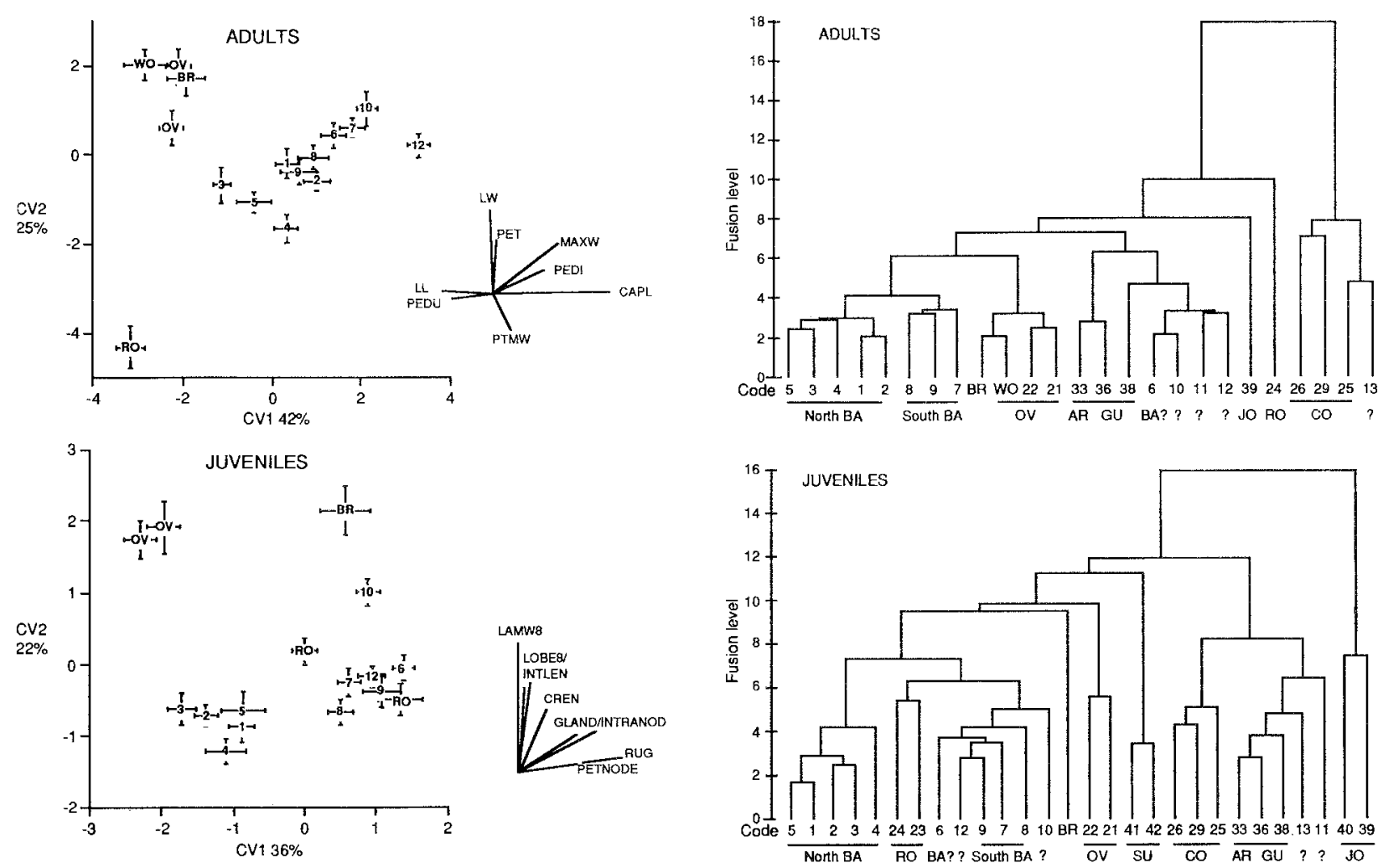

FIG. 2 - Population means and standard errors along the two major discriminant functions $(C V 1, C V 2)$ derived from the analysis of adult (upper) and juvenile (lower) population samples from northern (sites 1-5) and southern (sites 6-9) populations of Eucalyptus barberi, E. brookeriana $(B R)$, E. ovata (OV, WO), E. rodwayi (RO) and green phenotypes resembling E. barberi from Meredith Tier (site 10) and Ponybottom Creek (site 12). Vectors represent the direction (derived from the standardised discriminant function coefficients) and magnitude (derived from the univariate F-values) of variation in characters between populations. The percentage of the total variance explained by each discriminant function is indicated. (Location codes detailed in table 1.)

any of the three species. Where there is phenetic overlap between species, some individuals may fall within the $95 \%$ confidence intervals of more than one species; hence, the proportions may sum to more than $100 \%$. In the juveniles, only the proportion that matched the phenotype of $E$. barberi was calculated, since samples sizes of juvenile $E$. gunnii and $E$. cordata were insufficient to represent the species' full phenetic ranges.

\section{RESULTS}

The mean scores of the series Foveolatae populations on the first two discriminant axes derived from the adult and juvenile data are shown in figure 2. Clusters produced from this analysis proved to be subsets of those produced by the analysis including other species (fig. 3).

E. barberi (sites 1-9) and green samples from Meredith Tier and Ponybottom Creek with apparent affinities to E. barberi (sites 10,12) were well separated from the other Foveolatae species (BR, OV, WO, RO) in the discriminant space derived from the analysis of adult morphological

FIG. 3 - Dendrogram from average linkage clustering of adults (upper) and juveniles (lower) from populations of Eucalyptus barberi $(B A)$, E. brookeriana $(B R)$, E. ovata $(O V)$, E. rodwayi $(R O)$, E. archeri $(A R), \mathrm{E}$ gunnii $(G U)$, E. cordata (CO), E. johnstonii (JO), E. subcrenulata (SU) and aberrant populations (?). (Location codes detailed in table 1.)

traits. However, they were not well differentiated from E. rodwayi (RO) in the juvenile analysis (figs $2 \& 3$ ). E. ovata (OV, WO) was quite distinct from $E$. barberi and E. rodwayi (RO) in adult and juvenile morphology. E. brookeriana is closer to E. ovata in adult morphology, particularly the northwestern samples (WO, fig. 3), but equidistant and distinct from other species in juvenile morphology.

On juvenile morphology, E. barberi populations fell into two distinct groups: sites $1-5$ and sites 6-9, 10, 12 (fig. 3). These correspond geographically to a northern and a southern group (fig. 1). In the cluster analysis, which incorporates a larger proportion of variation than the ordination, this pattern is also apparent in the adults (fig. 3). Southern populations (sites 6-9, 10,12) exhibited greater variation in adult than juvenile morphology. In particular, the green samples with apparent affinities to $E$. barberifrom Meredith Tier (sites 6, 10) and Ponybottom Creek (site 12) were separated from other southern populations of $E$. barberi (fig. 3). The northern and southern E. barberi populations differed in capsule traits (larger, more pedicellate capsules in southern populations), and seedlings from southern populations retained the juvenile foliage longer than northern populations (expressed as higher node of first intranode and petiole; fig. 2).

At Meredith Tier (sites 10-11) and Ponybottom Creek (sites 12-13), phenotypes varied from narrow, green-leaved individuals with seven medium-sized fruit per umbel, typical of E. barberi, to individuals with broad, glaucous leaves and three large fruit per umbel, resembling E. cordata. The 
TABLE 3

Comparison of samples with the phenotypic ranges of three eucalypt species*

\begin{tabular}{|c|c|c|c|c|c|c|c|c|}
\hline \multirow{2}{*}{ Collected as } & & \multirow[b]{2}{*}{$\begin{array}{l}\text { Code } \\
\text { (Site) }\end{array}$} & & \multicolumn{5}{|c|}{ Classification ${ }^{\dagger}$} \\
\hline & & & & $\begin{array}{c}\text { E. barberi } \\
\%\end{array}$ & $\begin{array}{c}\text { E. cordata } \\
\%\end{array}$ & $\begin{array}{c}\text { E. gunnii } \\
\%\end{array}$ & $\begin{array}{c}\text { None test } \\
\text { sp. } \%\end{array}$ & $\mathrm{rr}$ \\
\hline \multirow[t]{18}{*}{ E. barberi } & & 1 & adults & 100 & 0 & 17 & 0 & 12 \\
\hline & & & juveniles & 100 & - & - & -. & 22 \\
\hline & & 2 & adults & 100 & 0 & 18 & 0 & $1 \mathrm{j}$ \\
\hline & & & juveniles & 96 & - & $\ldots$ & $\ldots$ & 24 \\
\hline & & 3 & adults & 100 & 0 & 0 & 0 & 9 \\
\hline & & & juveniles & 100 & $\ldots$ & - & - & 23 \\
\hline & & 4 & adults & 100 & ) & 0 & 0 & 12 \\
\hline & & & juveniles & 94 & -. & - & _- & 16 \\
\hline & & 5 & adults & 100 & 0 & 0 & 0 & 10 \\
\hline & & & juveniles & 83 & - & - & - & 18 \\
\hline & & 6 & adults & 45 & 0 & 27 & 36 & 11 \\
\hline & & & juveniles & 63 & - & - & - & 35 \\
\hline & & 7 & adults & 100 & 0 & 8 & 0 & 13 \\
\hline & & & juveniles & 92 & - & - & - & 25 \\
\hline & & 8 & adults & 100 & 0 & 11 & 0 & 9 \\
\hline & & & juveniles & 91 & - & - & - & 22 \\
\hline & & 9 & adults & 89 & 0 & 11 & 11 & 9 \\
\hline & & & juveniles & 86 & - & - & -- & 21 \\
\hline \multirow[t]{6}{*}{ Meredith Tier } & green & 10 & adults & 57 & 0 & 43 & 29 & 7 \\
\hline & & & juveniles & 59 & - & - & - & 29 \\
\hline & intermediate & - & adults & 43 & 0 & 30 & 44 & 23 \\
\hline & & & juveniles & 27 & - & - & - & 96 \\
\hline & glaucous & 11 & adults & 13 & 0 & 13 & 88 & 8 \\
\hline & & & juveniles & 14 & - & - & - & 37 \\
\hline \multirow[t]{6}{*}{ Ponybottom $\mathrm{Ck}$} & green & 12 & adults & 30 & 0 & 40 & 50 & 10 \\
\hline & & & juveniles & 51 & - & - & - & 37 \\
\hline & intermediate & - & adults & 0 & 0 & 0 & 100 & 13 \\
\hline & & & juveniles & 45 & - & - & - & 42 \\
\hline & glaucous & 13 & adults & 0 & 10 & 0 & 90 & 10 \\
\hline & & & juveniles & 12 & - & - & - & $4 !$ \\
\hline \multicolumn{9}{|l|}{ Summary: } \\
\hline \multirow[t]{2}{*}{ E. barberi } & & all & adults & 93 & 0 & 10 & 5 & 96 \\
\hline & & & juveniles & 88 & - & - & - & 206 \\
\hline \multirow[t]{2}{*}{ E. cordata } & & all & adults & 0 & 100 & 0 & 0 & 76 \\
\hline & & & juveniles & 0 & - & - & - & 37 \\
\hline \multirow[t]{2}{*}{ E. gunnii } & & all & adults & 11 & 0 & 96 & 3 & 76 \\
\hline & & & juveniles & 7 & - & - & - & 46 \\
\hline \multirow[t]{2}{*}{ Meredith Tier } & & all & adults & 39 & 0 & 30 & 50 & 38 \\
\hline & & & juveniles & 30 & - & - & - & 162 \\
\hline \multirow[t]{2}{*}{ Ponybottom Ck } & & all & adults & 9 & 3 & 12 & 82 & 33 \\
\hline & & & juveniles & 36 & - & - & - & 120 \\
\hline
\end{tabular}

* The percentage of individuals in each sample which were not significantly different $(\mathrm{p}>0.05)$ from $E$. barberi, $E$. cordata and $E$. gunnii, and the percentage matching none of the reference species. The percentage of individuals of the reference species which were not significantly different from the reference groups is shown, for comparison with samples from Meredith Tier and Ponybottom Creek. Dash (-) indicates sample nor tested. Due to overlap between reference groups, percentage may not total $100 \%$.

† Based on generalised distance. 
MEREDITH TIER

sites $10-11$

\section{PONYBOTTOM CREEK}

sites $12-13$
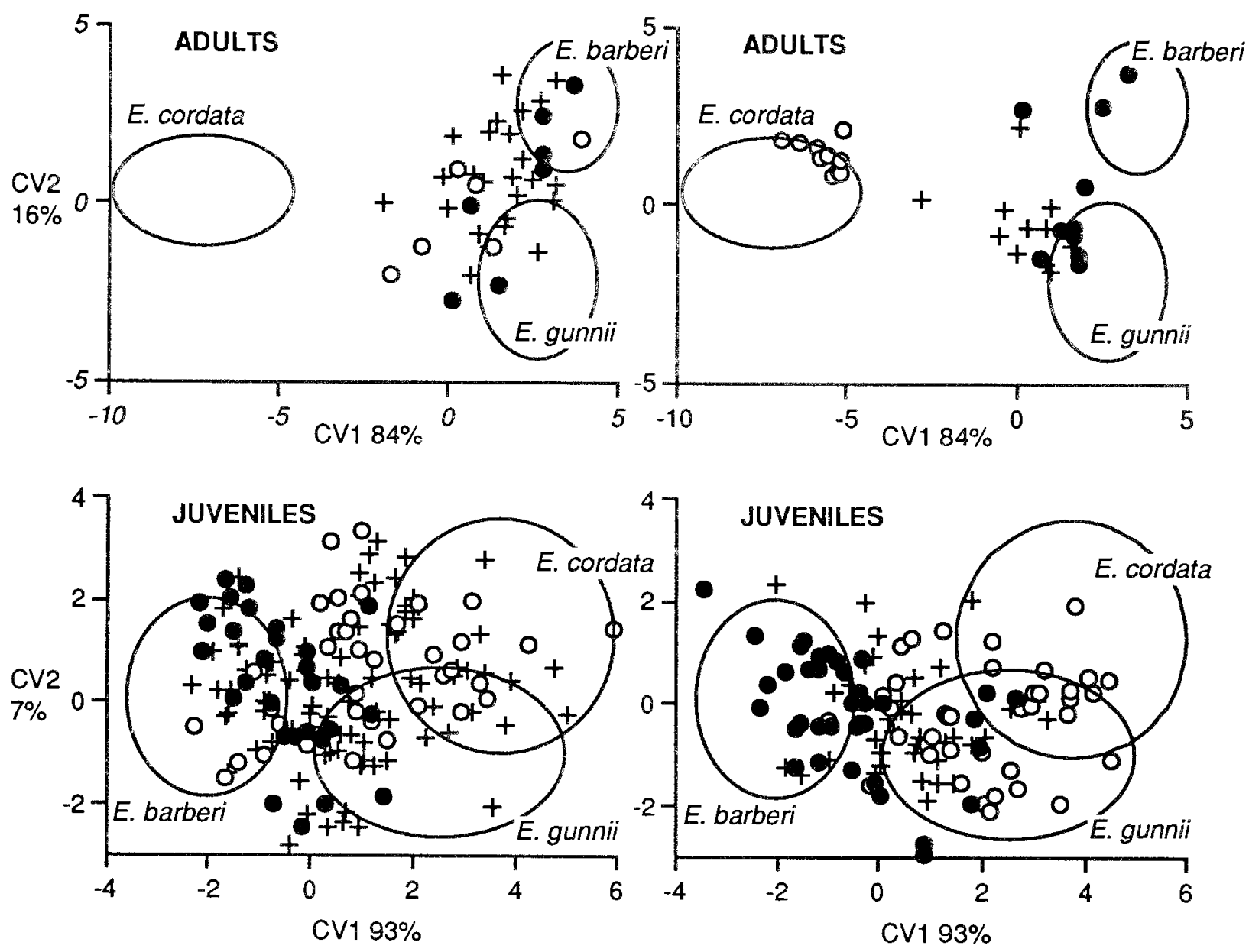

FIG. 4 - Plots of adults (upper) and juveniles (lower) from Meredith Tier (left) and Ponybottom Creek (right) on the axes derived from the discriminant analysis of typical Eucalyptus barberi, E. cordata and $\mathrm{E}$. gunnii samples. The percentage of variance represented by each discriminant function is shown. Ellipses represent the $95 \%$ confidence intervals for individuals of the three reference species. - green adults resembling E. barberi (upper), and their juvenile progeny (lower). 0 - glaucous adults and their juvenile progeny. + - intermediate adults and their juvenile progeny.

slightly isolated populations at Meredith Tier (site 6) and Ringrove Razorback (site 9) resembled E. barberi in leaf characters, but varied in bud number, from three to seven per umbel. E. gunnii, which occurs in the vicinity of the Meredith Tier population, has narrow adult leaves similar to E. barberi, but has three small buds per umbel.

Samples from Meredith Tier and Ponybortom Creek were ordinated in the discriminant space differentiating core populations of E. barberi, E. cordata and E. gunnii (fig. 4). Overlap of the juvenile discriminant scores of the reference $E$. cordata and E. gunnii populations (fig. 4, ellipses) indicates that these species were less distinct from one another in the juvenile than adult stages. Tests of the significance of the generalised distance between individuals and the centroids of the three reference species are shown in table 3. It is expected, in theory, that 95\% of typical species' samples would not differ significantly from the corresponding reference group. In this case, $93-100 \%$ of adults of the three species and $88 \%$ of $E$. barberi juveniles were correctly classified. There was some overlap in the ranges of $E$. barberi and E. gunnii adults, with $8-10 \%$ of adults of both species falling within the $95 \%$ confidence intervals of the other species.

The pattern observed for the reference populations contrasts markedly with the classification results from the anomalous populations at Meredith Tier and Ponybottom Creek. Most adults from Meredith Tier fell outside the $95 \%$ confidence intervals of all three reference species; $50 \%$ overall and $88 \%$ of the glaucous individuals were outside the confidence intervals of all the reference species (table 3 ). Those that did match were similar to E. barberi and E. gunnii in approximately equal proportions (39\% and $30 \%$ respectively) and, overall, the Meredith Tier population showed similarities to E. gunnii in the cluster analysis (fig. 3). The adults from Meredith Tier deviated slightly toward, but were not within the phenotypic range of $E$. cordata (fig. 4). A large proportion of the juveniles from Meredith Tier were also outside the ranges of all three reference species and most were intermediate between the reference species (fig. 4). Cluster analysis of the juveniles placed the green sample 
from Meredith Tier (site 10) as an outlier to the E. barberi populations and the glaucous sample (site 11) closest to E. gunnii (fig. 3).

In the full multidimensional space, $82 \%$ of the Ponybottom Creek adults were outside the $95 \%$ confidence intervals of all three reference species (table 3 ), with a small proportion of the remainder ascribed to each species. The green individuals (site 12) were divided between E. barberi $(30 \%)$ and E. gunnii (40\%). Only one individual from the intermediate and glaucous (site 13) samples matched a reference species ( $E$. cordata), but the glaucous individuals appeared closest to the $E$. cordata populations in the cluster analysis (fig. 3), and were very close to the adult phenotype of E. cordata (fig. 4). A greater proportion of Ponybottom Creek juveniles matched the phenotype of E. barberi (36\%) compared with the adults ( $9 \%$, table 3$)$. Most juveniles appeared intermediate between E. barberi and E. gunnii, but there was overlap with, and deviation toward the phenotypic range of E. cordata (fig. 3).

The range of variants observed in the juvenile progeny from both Meredith Tier and Ponybottom Creek (from all phenotypic classes collected) and the intermediate phenotypes of the parents strongly suggested parental heterozygosity rather than simple outcrossing. For example, recombination of leaf shape and glaucousness was very apparent in progeny of one intermediate individual from Meredith Tier.

\section{DISCUSSION}

Significant differentiation, in both adult and juvenile characters, was found between most populations of E. barberi. A seedling trial clearly indicated that this differentiation has a strong genetic basis. There appeared to be a primary division between a northern group of populations that may be designated "typical" E. barberiand other, southern, populations which deviated toward the phenotype of other species (fig. 1). There was no clear clinal or consistent spatial pattern of variation within each group. The "typical" group comprised populations from Cherry Tree Hill (sites 3-4), Brushy Creek (site 5) and the vicinity of Blindburn Creek (sites $\mathrm{I}-2$, in the DouglasApsley National Park). Within this group, phenetic distance was poorly correlated with geographic distance. The southern group comprised E. barberi populations from Ravensdale Hill (site 8), $1.5 \mathrm{~km}$ south of Lily Flats (site 7) and the green phenotypes resembling E. barberi from Meredith Tier $(6,10)$, Ponybottom Creek (site 12) and Ringrove Razorback (site 9). Some southern populations showed affinities to juvenile E. rodwayi but were quite distinct on adult traits. Conversely, several of the southern populations (sites $6,10,12$ ) showed affinities toward E. gunnii in their adult morphology (fig. 3) but were clearly differentiated from E. gunnii and E. archeri on juvenile morphology. In most cases, they would also have been differentiated from these species on the basis of the number of buds per inflorescence, which was not included in the analysis (and was greater than the typical three of E. gunnii and $E$. archeri). They, therefore, appear to have closest affinities to $E$. barberi.

The high level of population differentiation found within $E$. barberi is typical of the population genetic structure that would be predicted by theory for a species distributed as a series of small disjunct populations (due to factors such as genetic drift - Falconer 1986) and has been observed in other eucalypt species with comparable distribution patterns (e.g. E. caesia, E. pendens-Moran \& Hopper 1987; E. crucis - Sampson et al. 1988). Prober et al. (1990) suggest that such restricted distributions may result from recent divergence (with insufficient time for geographical radiation), barriers to dispersal (e.g. unsuitability of habitat, competition), or contraction of the range of an older species due to environmental factors (e.g. habitat specificity, climatic change). In this case, the degree and pattern of phenetic differentiation between $E$. barberi populations and the large disjunctions in its geographical range support Williams' (1990) contention that $E$. barberi is not a recently diverged species. E. barberi appears to be a relic species and has possibly been displaced from intervening sites by competition with more rapidly growing species.

It is only possible to speculate on the cause of differentiation in E. barberi. Genetic drift, localised selection, hybridisation and historical factors may all be involved. Kirkpatrick \& Brown (1984a, b) and Potts \& Reid (1985c) suggested that the present east coast flora may have originated from populations which differentiated in two glacial refugia. Such separation could explain differentiation of the northern and southern populations of E. barberi. However, the disjunct distribution of $E$. barberi does not appear to have been caused by insufficient time for radiation, as the major disjunction in the geographical distribution of E. barberi does not correspond to the phenetic disjunction (fig. 1). This contrasts with the coincidence of marked genetic differentiation with geographic disjunction in E. tenuiramis in the same area (Wiltshire et al. 1992). Disjunctions in the geographical distribution of E. barberi may not be as extensive as is shown by current records. Paucity of sampling may have occurred, due to the small population sizes (and area), inaccessibility and small size of the trees. There are, for example, unverified reports of other populations west of Triabunna (between sites $12-13$ and site 8 ).

"Confusing intermediacy" (Kirkpatrick \& Brown 1984b) is an apt description of the Meredith Tier and Ponybottom Creek populations. At both sites, the pattern of high diversity and intermediacy of parents and progeny, coupled with the high variability within some families, was consistent with a hybrid swarm, several generations old (e.g. Potts \& Reid 1985a). The magnitude of the differences between extreme phenotypes was strongly suggestive of hybridisation, as was the distribution of extreme phenotypes at Meredith Tier. Although this may have been produced by disruptive selection from the gene pool of one species, no selective agency of sufficient magnitude was evident, particularly at Ponybottom Creek. At both localities, trees with close affinities to E. barberi appeared to be one of the parents. The exact identity of the other parent remains unclear. E. cordata, E. gunniz and possibly E. morrisbyi are the only plausible extant species. E. morrisbyi was not included in the progeny trial because of its extremely limited distribution (Wiltshire et al. 1990), and the fact that its juveniles would be difficult to distinguish from E. gunnii in hybrid combination (e.g. Potts 1989). At both Meredith Tier and Ponybottom Creek, extreme phenotypes did not resemble other members of the Foveolatae, and the involvement of E. johnstonii or E. subcrenulata, which has been reported from near Ponybottom Creek and on the Eastern Tiers (Brown et al. 1983), is unlikely, as the juveniles of these taxa are clearly differentiated from those of E. barberi and populations at Meredith Tier and Ponybottom Creek (fig. 3). 
The unusual characteristics of the latter populations may have resulted from hybridisation between atypical populations of the species suggested. Such small, atypical populations of both E. cordata (Potts 1989) and E. gunnii (Potts \& Reid 1985b) are numerous on the east coast and are still being found (e.g. E. cordata near Wielangta Hill, between site 12-13 and site 8 ). However, it remains to be ascertained whether the variation found at Meredith Tier and Ponybottom Creek and the deviation of these populations from typical E. barberi are due to past introgression or reflect genetic variation within $E$. barberi at these localities. Molecular techniques may best be able to resolve the identity of these populations.

\section{Conservation status}

At present one, albeit relatively large population of E. barberi is securely reserved, in the Douglas-Apsley National Park (sites 1-2). Another of the northern populations (Brushy Creek, site 5) is in the proposed Bluemans Creek state reserve (Williams 1989). Other populations, including the type locality (site 4), are unreserved. The type locality also contains other rare species (Spyridium microphyllum, Helichrysum lycopodioides, Melaleuca pustulata, Cyathodes pendulosa and Gabnia graminifolia - Duncan \& Duncan 1984) and has been previously recommended for reservation (Duncan \& Brown 1985).

There is a need to extend conservation measures to encompass the full range of variability in this species. In particular, the type locality, representatives of the southern phenetic group (e.g. "south of Lily flats" - site 7; "Ravensdale Hill" - site 8) and outlying populations such as Meredith Tier (sites 6, 10-11), Ringrove Razorback (site 9) and Ponybottom Creek (site 12-13) should be formally reserved. The latter populations are also of scientific interest. E. barberi populations are generally small, particularly the southern populations (table 1), which would argue for reservation of multiple representatives of each of the major phenetic groups.

\section{ACKNOWLEDGEMENTS}

Thanks to Fred Duncan and Kristen Williams for providing location information for E. barberi (from records of the Forestry Commission, Tasmania), and Rob Wiltshire for helpful comments on the manuscript.

\section{REFERENCES}

Barbiz, H.N., 1954: A sterile eucalypt. Pap. Proc. R. Soc. Tasm. 88: 285-287.

Brown, M.J., KirkPatrick, J.B. \& Moscal, A., 1983: AN ATLAS OF TASMANIA'S ENDEMIC FLORA. Tasmanian Conservation Trust, Tasmania.

Chilphivdalt, G.M., 1988: FLORA OF AUSTRAIIA, VOL. 19. EUCALYPTUS, ANGOPHORA (MYRTACEAE). Australian Government Publishing Service, Canberra.

Duncen, F., 1989: Systematic affinities, hybridisation and clinal variation within Tasmanian eucalypts. Tasforests $2: 13-$ 24.

Duncax, F. \& Brown, M.J., 1985: Dry schlerophyll vegetation in Tasmania. Extent and conservation status of the communities. Wildlife Div. Tech. Rep. 85/1. National Parks and Wildlife Service, Tasmania.
Duncan, F. \& Duncan, D., 1984: A dry sclerophyll woodland mosaic: vegetation of Cherry Tree Hill, near Cranbrook, Tasmania. Rec. Queen Vic. Mus. 85: 1-15.

Duncan, F., Harris, S. \& Brown, M.J., 1981: A descriptive account of the forests near Rocka Rivulet, Eastern Tiers. Tasm. Nat. 67: 4-11.

FAlCONER, D.S., 1986: INTRODUCTION TO QUANTITATIVE GENETICS. John Wiley and Sons, New York.

GrAY, A.M., 1979: A new species of Eucalyptus from Tasmania. Aust. For. Res. 9: 111-118.

Johnson, L. \& Blaxel, D., 1972: New taxa and combinations in Eucalyptus I. Contrib. NSW Nat. Herb. 4: 284-290.

KIRKPATRICK, J.B., 1981: A transect study of forests and woodlands on dolerite in the Eastern Tiers, Tasmania. Vegetatio 44 $155-163$

Kinkpatrick, J.B. \& Brown, M.J., 1984a: A numerical analysis of Tasmanian higher plant endemism. Bot. J. Limn. Soc. 88: $165-183$.

KuRKPATRICK, J.B. \& BRown, M.J., 1984b: The palacogcographic significance of local endemism in Tasmanian higher plants. Search 15: 112-113.

Ladigfs, P.Y., Gray, A.M. \& Brooker, M.I.H., 1981: Pattern of geographic variation, based on seedling morphology, in Eucalyptus ovata Labill. and E. brookeriana A. M. Gray and comparisons with some other Eucalyptus species. Aust. J. Bot. 29: 593-603.

Ladiges, P.Y., Dale, M.B., Ross, D.R. \& Shieids, K.G., 1984 Seedling characters and phylogenetic relationships in the informal series Ovatae of Eucalyptus, subgenus Symphyomyrtus. Aust. J. Bot. 32: 1-13.

MacPhall, M.K. \& Colmoln, E.A., 1985: Late last glacial vegetation, climates and fire activity in southwest Tasmania. Search 16: 43-45.

Moran, G.F. \& HopPER, S.D., 1987: Conservation of the genetic resources of rare and widespread eucalypts in remnant vegetation. In Saunders, D.A., Arnold, G.W., Burbidge, A.A. \& Hopkins, A.J.M. (Eds): NATURE CONSERVATION: THE ROLE OF REMNANTS OF NATIVE VEGETATION. Surrey Beatty and Sons, Chipping Norton: 151-162.

ORLOCI, L., 1978: MULTIVARIATE ANALYSIS IN VEGETATION RESEARCH. Dr W. Junk, The Hague.

PoTrs, B.M., 1989: Population variation and conservation status of a rare Tasmanian endemic, Eucalyptus cordata. Res. rep. 4. Tasmanian Forest Research Council Inc.

PotTs, B.M., 1990: The response of eucalypt populations to a changing environment. Tasforests 2: 179-193.

PotTs, B.M. \& Rew, J.B., 1985a: Analysis of a hybrid swarm between Eucalyptus risdonii Hook.f. and E. amygdalina Labill. Aust. J. Bot. 33: 543-562.

PorTs, B.M. \& ReiD, J.B., 1985b: Variation in the Eucalyptus gunnii-archeri complex. I. Variation in the adul phenotype. Aust. J. Bot. 33: 337-359.

PoTT'S, B.M. \& Rfild, J.B., 1985c: Variation in the Eucalyptus gunnii-archeri complex. II. The origin of variation. Aust. J. Bot. 33: 519-541.

Prober, S.M., Tompkins, C., Moran, G.F. \& Beil, J.C., 1990 The conservation genetics of Eucalyptus paliformis $\mathrm{L}$. Johnson et Blaxell and E. parvifolia Cambage, two rare species from south-eastern Australia. Aust. J. Bot. 38:7995.

PRYOR, L.D. \& BRIGGS, J.D., 1981: AUSTRALIAN ENDANGERED SPECIES: EUCALYPTS. Australian Narional Parks and Wildlife Service, Canberra.

Pryor, L.D. \& JoHNSON, L.A.S., 1971: A CLASSIFICATION OF THE EUCALYPTS. Australian National University Press, Canberra.

SAMPSON, J.F., Hopper, S.D. \& James, S.H., 1988: Genetic diversity and the conservation of Eucalyptus crucis Maiden. Aust. J. Bot. 36: 447-460. 
SAS, 1988: SAS/STATTM USER'S GUIDE RELEASE 6.03 EDITION. SAS Institute, Cary, NC.

Shaצ, M.J., PotTs, B.M. \& RkrD, J.B., 1984: Variation within and between Eucalyptus nitida Hook. f. and E. coccifera Hook. f. Aust. J. Bot. 32: 641-654.

SNEATH, P.H.A. \& SOKAL, R.R., 1973: NUMERICAL TAXONOMY. W.H. Freeman and Co., San Francisco.

WIL LAMS, K., 1989: DRY SCLEROPHYLL FOREST IN TASMANIA. RECOMMENDED AREAS FOR PROTECTION. A Report to the Working Group for Forest Conservation. Tasmanian Forestry Commission, Hobart.

WiIr.iams, K., 1990: Environmental modelling of Tasmanian plant species. Unpubl. BSc Hons thesis, Univ. Tasm.
Whitshike, R., PotTs, B.M. \& Rerd, J.B., 1990: Phenetic affinities, variability and conservation status of a rare Tasmanian endemic, Eucalyptus morrisbyi R. G. Bretr. In Banks, M.R., Smith, S.J., Orchard, A.E. \& Kanrvilas, G. (Eds): ASPECTS OF TASMANLAN BOTANY - A TRIBUTE TO WINIFRED CURTIS. Royal Society of Tasmania, Hobart: 213-229.

Writshike, R.J.E., Polis, B.M. \& Rhid, J.B., 1991: A paedomorphocline in Eucalyptus: Natural variation in the E. risdoniz/E. tenuiramis complex. Aust. J. Bot. 39: $545-566$.

Wirtshire, R.J.E., PotTs, B.M. \& Riid, J.B., 1992: A paedomorphocline in Eucalyptus. II: Variation in seedling morphology in the F. risdoniilE. tenuiramis complex. Aust. J. Bot. 40: 789-805.

(accepted 17 November 1993) 